\title{
Stabilization of Zwitterionic Structures of Amino Acids (Gly, Ala, Val, Leu, Ile, Ser, Pro) by Ammonium Ions in the Gas Phase
}

\author{
Ronghu Wu and Terry B. McMahon* \\ Department of Chemistry, University of Waterloo, Waterloo, Ontario, Canada N2L $3 G 1$
}

Supporting Information

References:

45. Gaussian 03, Revision B.04, Frisch, M. J.; Trucks, G. W.; Schlegel, H. B.; Scuseria, G. E.; Robb, M. A.; Cheeseman, J. R.; Montgomery Jr., J. A.; Vreven, T.; Kudin, K. N.; Burant, J. C.; Millam, J. M.; Iyengar, S. S.; Tomasi, J.; Barone, V.; Mennucci, B.; Cossi, M.; Scalmani, G.; Rega, N.; Petersson, G. A.; Nakatsuji, H.; Hada, M.; Ehara, M.; Toyota, K.; Fukuda, R.; Hasegawa, J.; Ishida, M.; Nakajima, T.; Honda, Y.; Kitao, O.; Nakai, H.; Klene, M.; Li, X.; Knox, J. E.; Hratchian, H. P.; Cross, J. B.; Adamo, C.; Jaramillo, J.; Gomperts, R.; Stratmann, R. E.; Yazyev, O.; Austin, A. J.; Cammi, R.; Pomelli, C.; Ochterski, J. W.; Ayala, P. Y.; Morokuma, K.; Voth, G. A.; Salvador, P.; Dannenberg, J. J.; Zakrzewski, V. G.; Dapprich, S.; Daniels, A. D.; Strain, M. C.; Farkas, O.; Malick, D. K.; Rabuck, A. D.; Raghavachari, K.; Foresman, J. B.; Ortiz, J. V.; Cui, Q.; Baboul, A. G.; Clifford, S.; Cioslowski, J.; Stefanov, B. B.; Liu, G.; Liashenko, A.; Piskorz, P.; Komaromi, I.; Martin, R. L.; Fox, D. J.; Keith, T.; AlLaham, M. A.; Peng, C. Y.; Nanayakkara, A.; Challacombe, M.; Gill, P. M. W.; Johnson, B.; Chen, W.; Wong, M. W.; Gonzalez, C.; Pople, J. A. Gaussian, Inc., Pittsburgh PA, 2003. 
Table S1. Calculated values of enthalpy and entropy changes of the association reactions related to different isomers of leucine or isoleucine with ammonia.

\begin{tabular}{lcccc}
\hline & \multicolumn{3}{c}{$\mathrm{B} 3 \mathrm{LYP} / 6-311+\mathrm{G}(\mathrm{d}, \mathrm{p})$} & $\begin{array}{c}\text { MP2(full)/6-311++G(2d, 2p) } \\
/ / \mathrm{B} 3 \mathrm{LYP} / 6-311+\mathrm{G}(\mathrm{d}, \mathrm{p})\end{array}$ \\
\cline { 2 - 4 } & $\begin{array}{c}\Delta \mathrm{H}_{0} \\
\left(\mathrm{kcal} \mathrm{mol}^{-1}\right)\end{array}$ & $\begin{array}{c}\Delta \mathrm{H}_{298} \\
\left(\mathrm{kcal} \mathrm{mol}^{-1}\right)\end{array}$ & $\begin{array}{c}\Delta \mathrm{S} \\
\left(\mathrm{cal} \mathrm{mol}^{-1} \mathrm{~K}^{-1}\right)\end{array}$ & $\begin{array}{c}\Delta \mathrm{H}_{298}{ }^{2} \\
\left(\mathrm{kcal} \mathrm{mol}^{-1}\right)\end{array}$ \\
\hline LN1 & -22.7 & -22.5 & -29.3 & -21.6 \\
LN2 & -21.9 & -20.5 & -27.5 & -20.8 \\
LN3 & -22.0 & -21.3 & -29.0 & -20.3 \\
LN4 & -20.5 & -19.3 & -33.0 & -19.6 \\
& & & & -21.9 \\
IN1 & -22.5 & -22.3 & -28.4 & -20.6 \\
IN2 & -21.5 & -20.1 & -26.2 & -19.8 \\
IN3 & -21.2 & -20.5 & -27.6 & -19.6 \\
IN4 & -20.1 & -19.0 & -31.6 & \\
\hline
\end{tabular}

${ }^{a}$ ZPEs and thermal energy corrections are from the calculation results by B3LYP/6-311+G(d, p); 


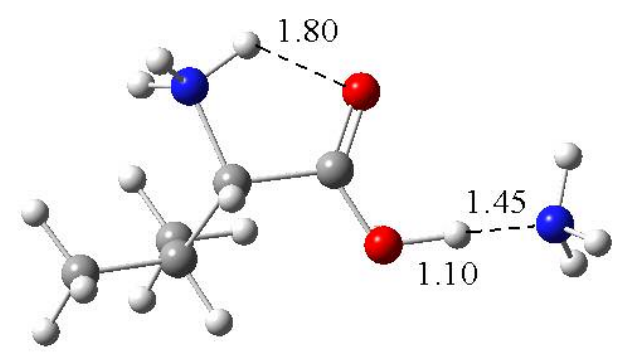

VN1

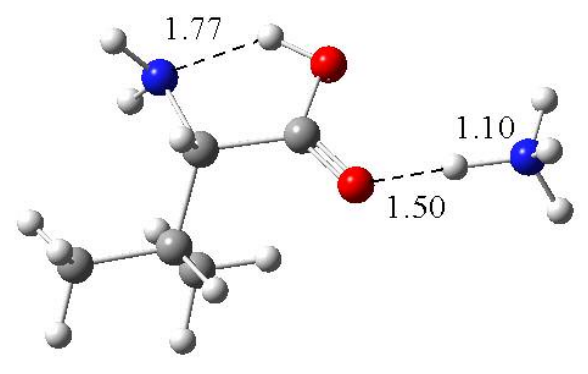

VN3

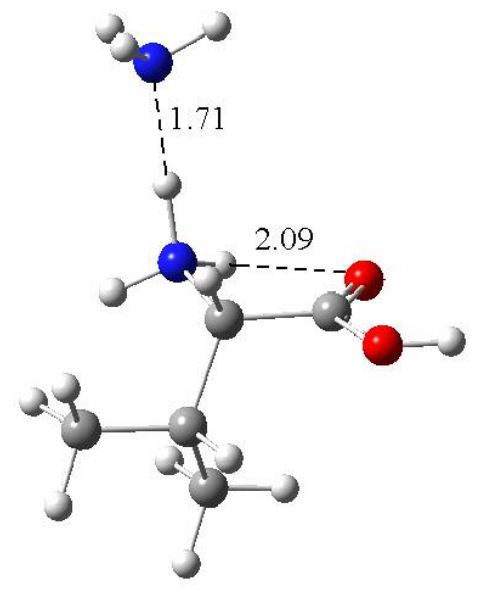

VN2

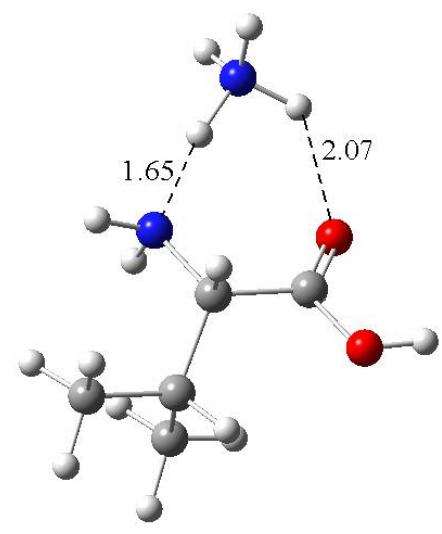

VN4

Figure S1. Structures of the four most stable isomers of the cluster of protonated valine and ammonia obtained at the B3LYP/6-311+G(d, p) level of theory. 


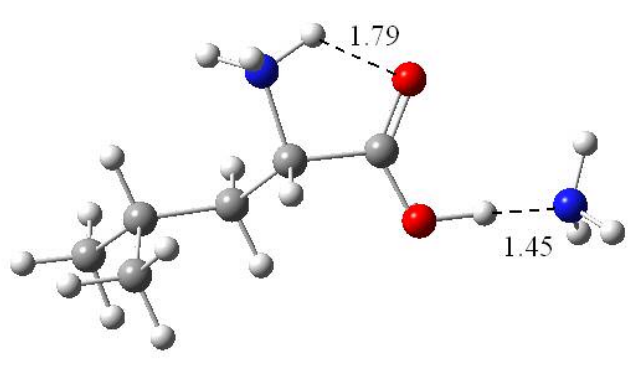

LN1

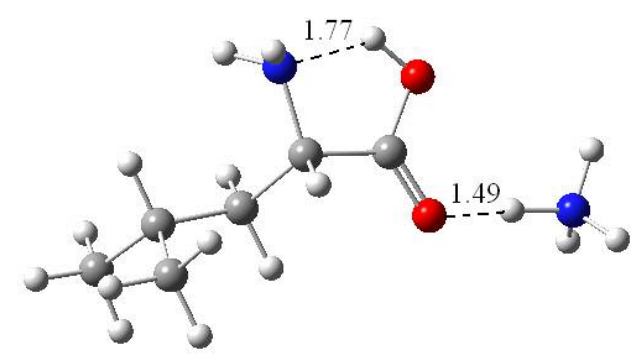

LN3

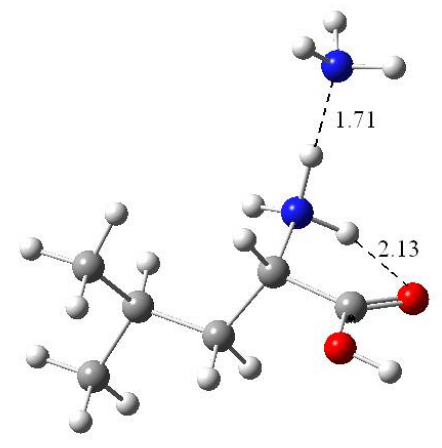

LN2

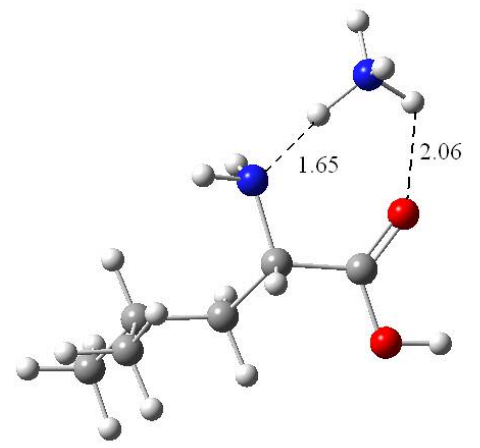

LN4

Figure S2. Structures of the four most stable isomers of protonated Leucine and ammonia obtained at the B3LYP/6-311+G(d, p) level of theory. 


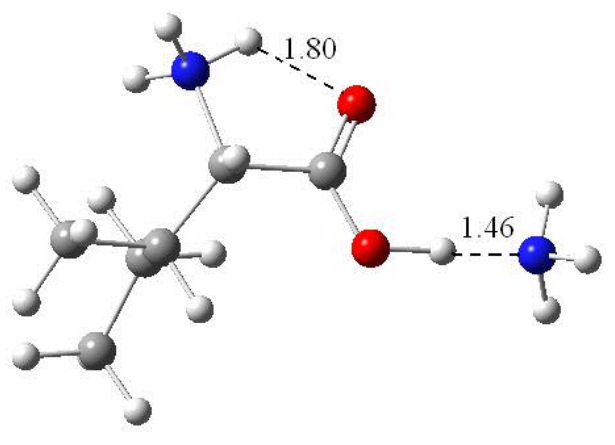

IN1

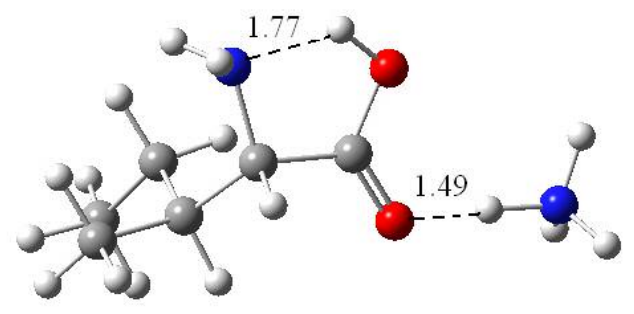

IN3

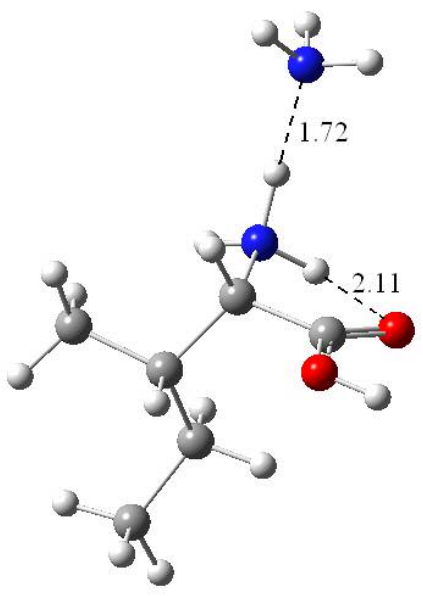

IN2

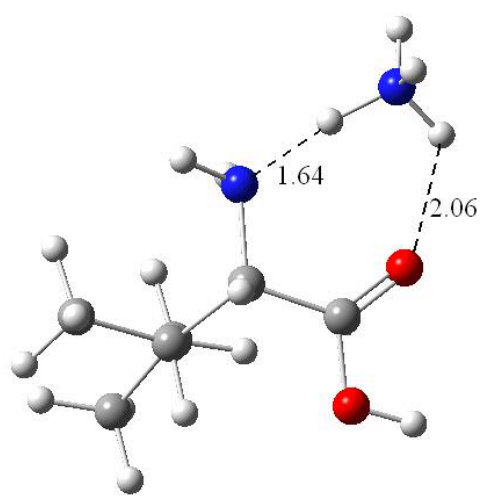

IN4

Figure S3. Structures of the four most stable isomers of protonated isoleucine and ammonia obtained at the B3LYP/6-311+G(d, p) level of theory. 


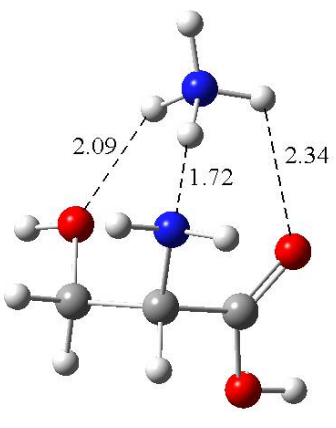

SN1

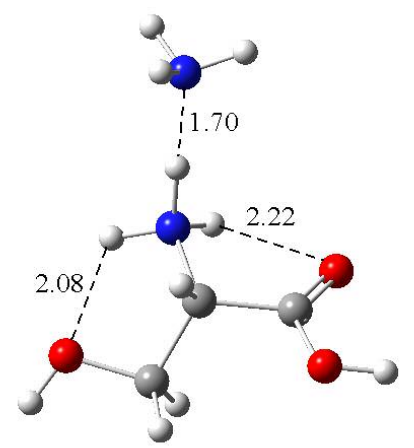

SN4

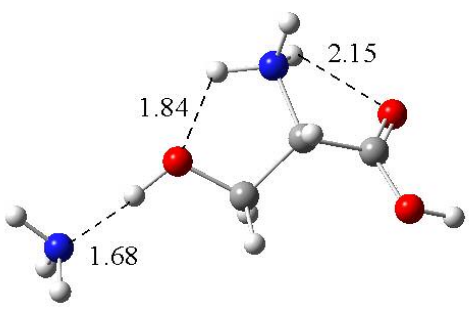

SN7

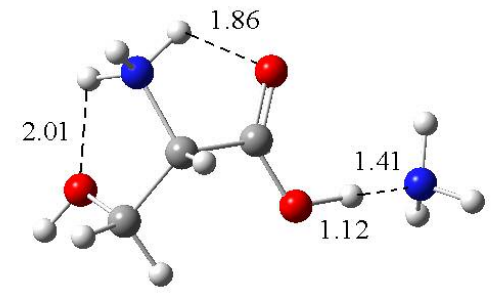

SN2

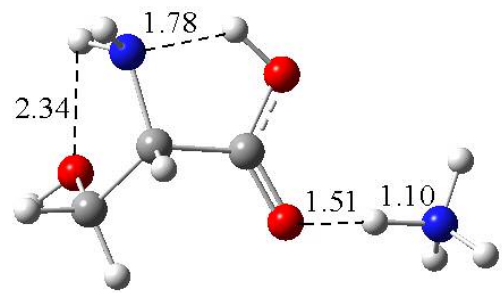

SN5

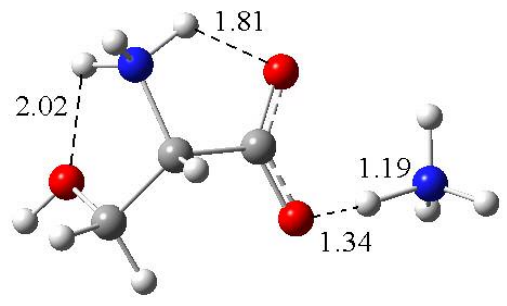

SN3

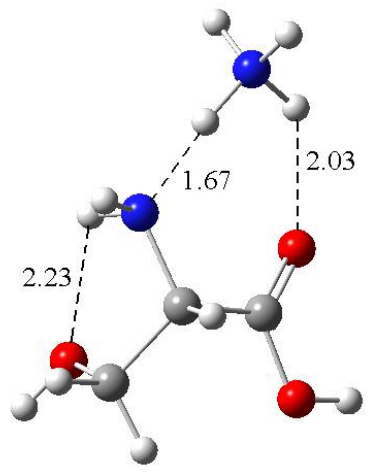

SN6

Figure S4. Structures of the seven most stable isomers of protonated serine and ammonia obtained at the B3LYP/6-311+G(d, p) level of theory. 


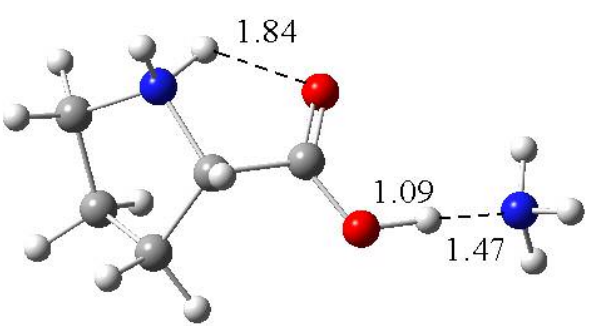

PN1

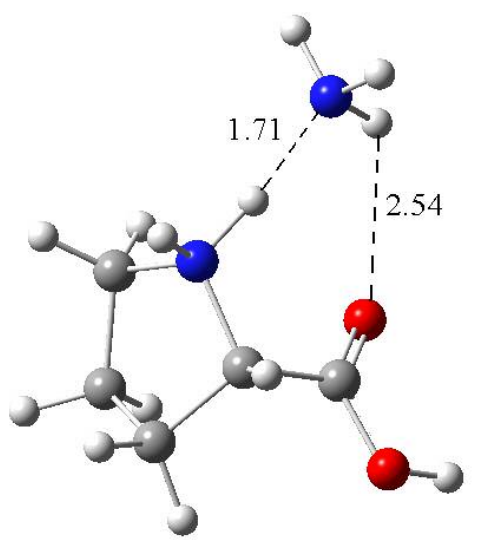

PN3

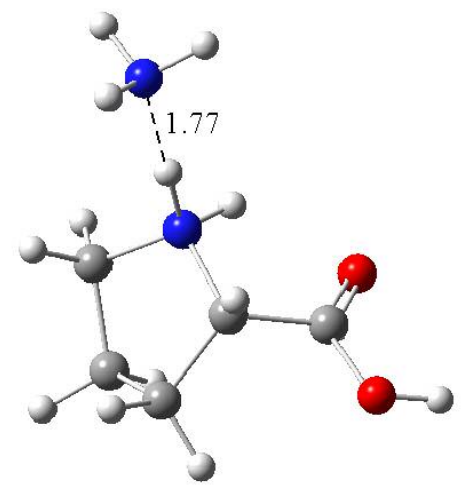

PN2

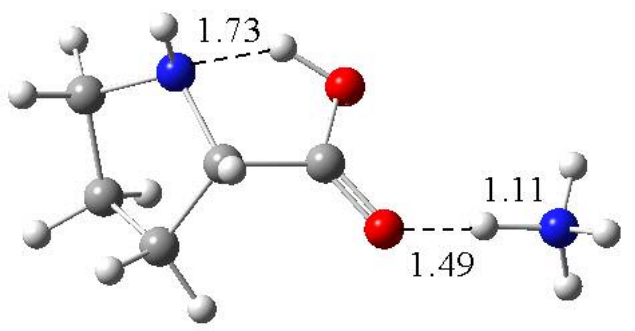

Figure S5. Structures of the four most stable isomers of protonated proline and ammonia obtained at the B3LYP/6-311+G(d, p) level of theory. 


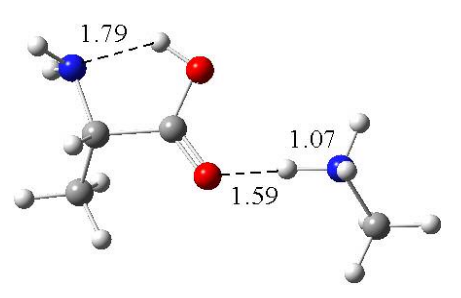

Ama1

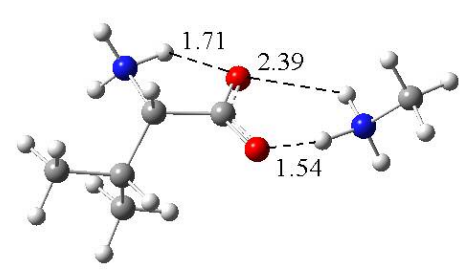

Vma1

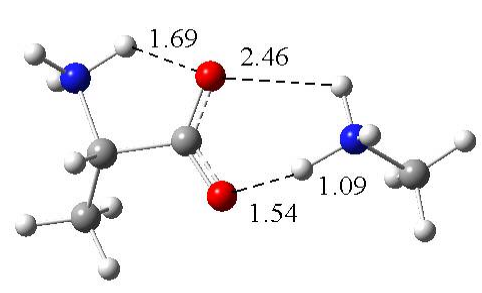

Ama2

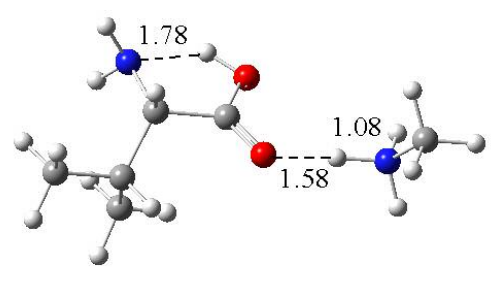

Vma2

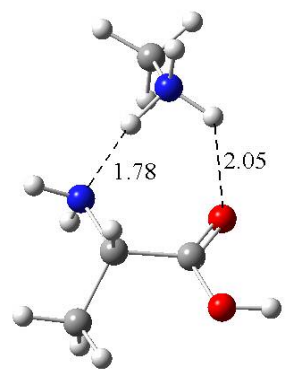

Ama3

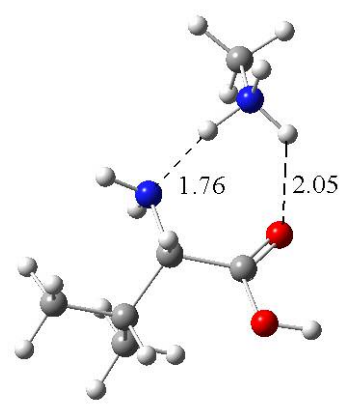

Vma3

Figure S6. Structures of the several most stable isomers of the cluster of protonated alaline and valine and methylamine obtained at the B3LYP/6-311+G(d, p) level of theory. 


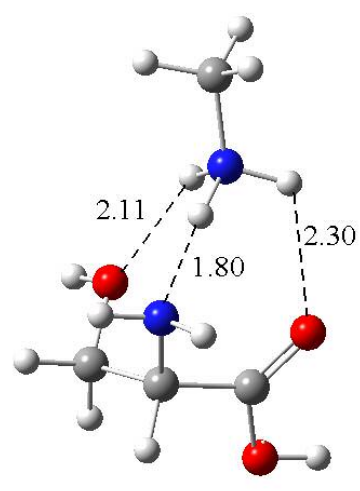

Sma1

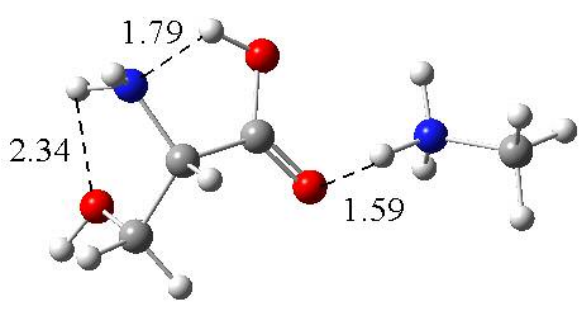

Sma3

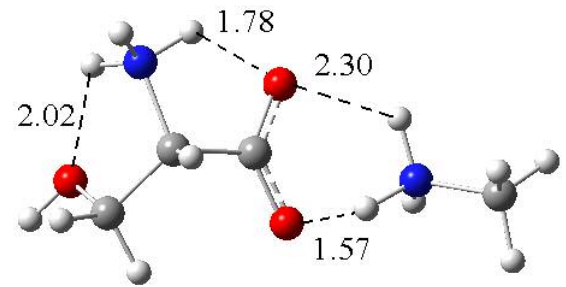

Sma2

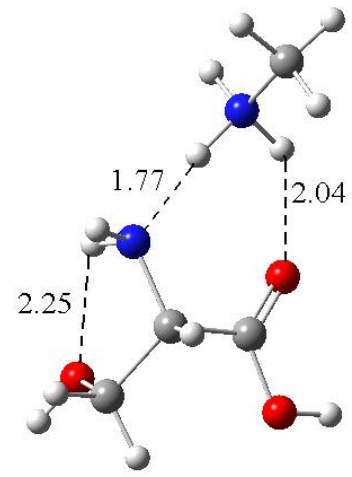

Sma4

Figure S7. Structures of the four most stable isomers of the cluster of protonated serine and methylamine obtained at the B3LYP/6-311+G(d, p) level of theory. 


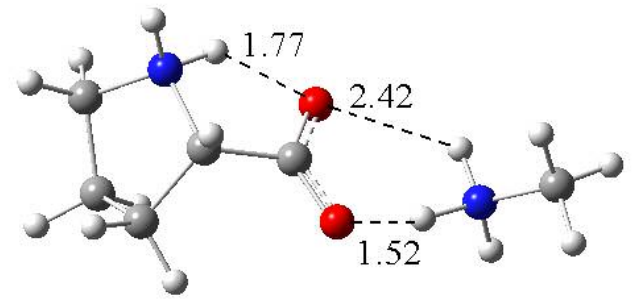

Pma1

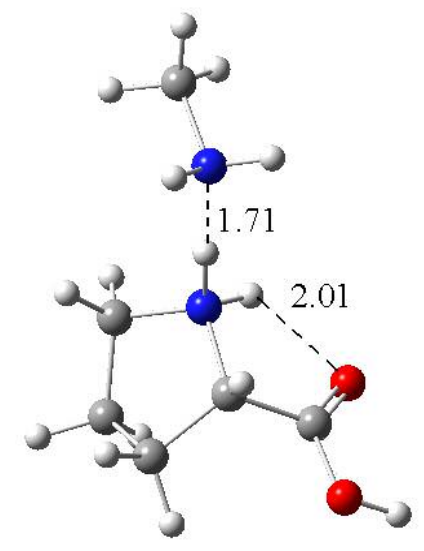

Pma3

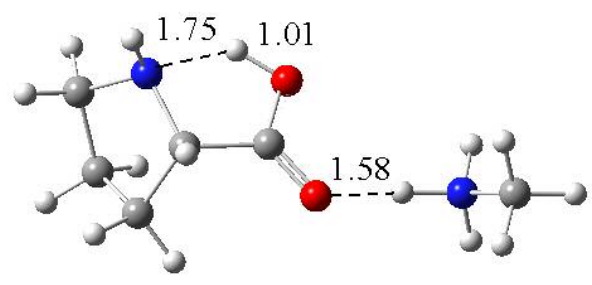

Pma2

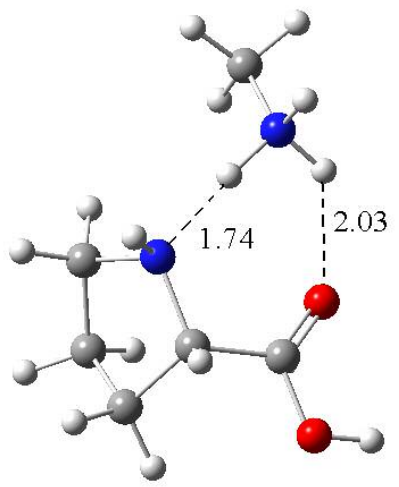

Pma4

Figure S8. Structures of the four most stable isomers of the cluster of protonated proline and methylamine obtained at the B3LYP/6-311+G(d, p) level of theory. 


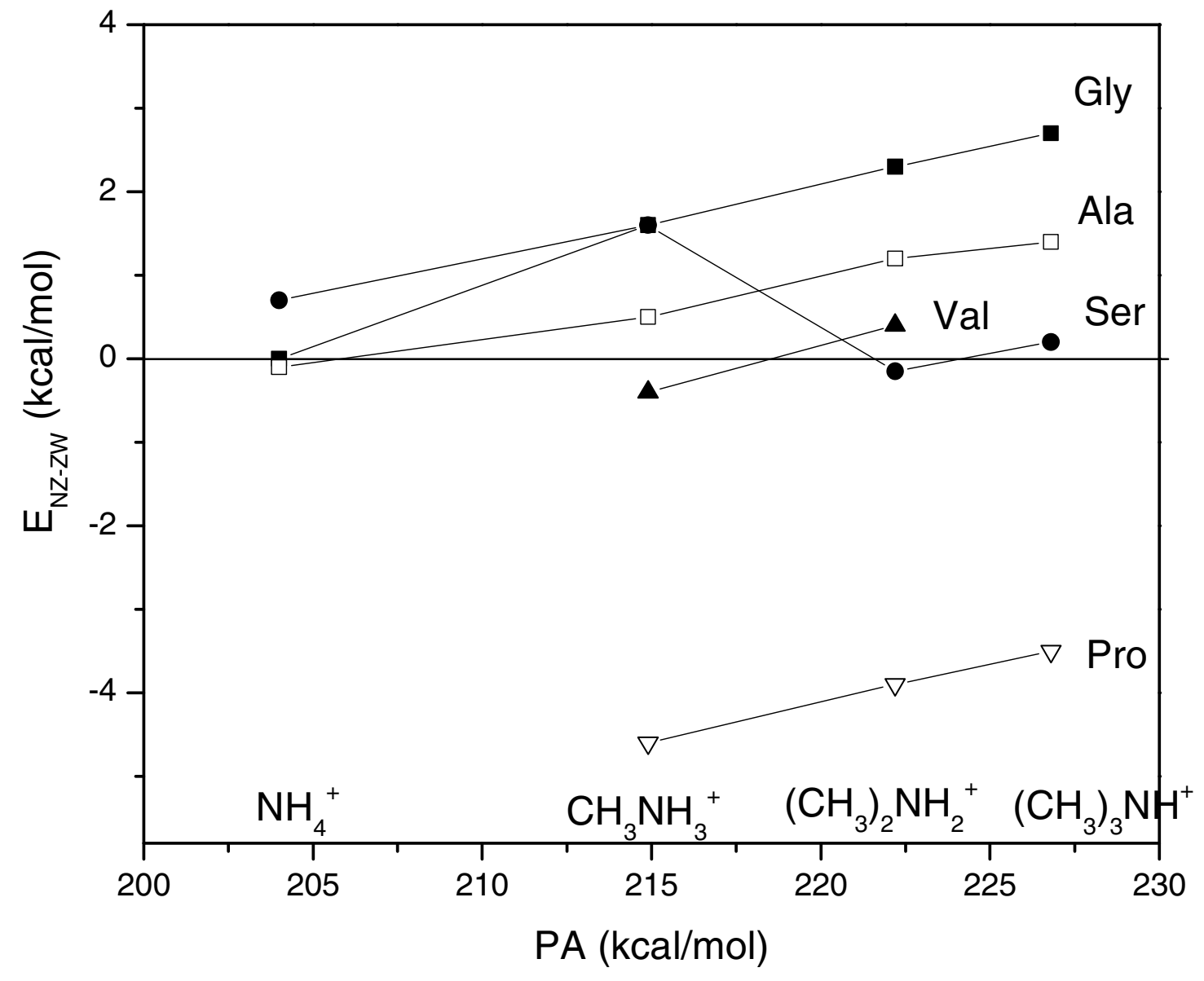

Figure S9. Relative stabilization of zwitterionic amino acids by ammonium ions, as expressed by the energy difference at $298 \mathrm{~K}$ between the most stable non-zwitterionic (NZ) and zwitterionic clusters (ZW) calculated at the MP2(full)/6-311++G(2d,2p)// B3LYP/6-311+G(d, p) level of theory, with the thermal corrections at $298 \mathrm{~K}$ obtained at B3LYP/6-311+G(d, p) level of theory. 